\title{
Genetic polymorphisms related to meat traits in purebred and crossbred Nelore cattle
}

\author{
Rogério Abdallah Curi(1), Marina Rufino Salinas Fortes(2), Luis Artur Loyola Chardulo(3), Antonio Carlos Silveira(1), \\ Mário De Beni Arrigoni ${ }^{(1)}$, Cyntia Ludovico Martins ${ }^{(1)}$, Mayra Elena Ortiz D’ Avila Assumpção(2) \\ and Henrique Nunes de Oliveira(1)
}

\begin{abstract}
(1)Universidade Estadual Paulista (Unesp), Faculdade de Medicina Veterinária e Zootecnia, Departamento de Melhoramento e Nutrição Animal, Fazenda Experimental Lageado, CEP 18618-000 Botucatu, SP, Brazil. E-mail: rogcuri@yahoo.com.br, acsilveira@fca.unesp.br, arrigoni@fca.unesp.br, cludovico@fca.unesp.br, hnunes@fca.unesp.br (2)Universidade de São Paulo, Faculdade de Medicina Veterinária e Zootecnia Departamento de Reprodução Animal, CEP 05508-010 São Paulo, SP, Brazil. E-mail: m.fortes@uq.edu.au, meoaa@usp.br (3)Unesp, Instituto de Biociências, Departamento de Química e Bioquímica, Distrito de Rubião Júnior, s/no, CEP 18618-000 Botucatu, SP, Brazil. E-mail: lachard@ibb.unesp.br
\end{abstract}

\begin{abstract}
The objective of this work was to estimate the allelic and genotypic frequencies of CAST/XmnI, a calpastatin gene polymorphism, and CAPN530, a calpain 1 large subunit gene polymorphism, in different beef genetic groups (Nelore and Nelore x Bos taurus), and to investigate associations between these polymorphisms and carcass and meat traits. Three hundred animals - comprising 114 Nelore, 67 Angus x Nelore, 44 Rubia Gallega x Nelore, 41 Canchim, 19 Brangus three-way cross and 15 Braunvieh three-way cross - were genotyped by PCR-RFLP and phenotyped for rib-eye area (REA), back-fat thickness (BT), intramuscular fat (IF), shear force (SF) and myofibrillar fragmentation index (MFI). The occurrence of the two alleles of the CAST/XmnI and CAPN530 single nucleotide polymorphisms (SNPs) in a B. indicus breed, which permitted association studies in purebred and crossbred Nelore cattle, was first shown in the present work. No relationship was found between the CAST or CAPN1 SNPs and growth-related traits (REA) or fat deposition (BT and IF), since calpastatin and $\mu$-calpain are not physiologically involved with these traits. Moreover, the association results between genotypes and aged meat tenderness (assessed by SF and MFI) showed that these markers are useless in assisted selection for purebred Nelore and their crosses with B. taurus.
\end{abstract}

Index terms: Bos indicus, calpain gene, calpastatin gene, meat tenderness, single nucleotide polymorphisms.

\section{Polimorfismos genéticos relacionados às características da carne em bovinos Nelore puros e cruzados}

Resumo - O presente trabalho objetivou estimar, em bovinos de corte de diferentes grupos genéticos (Nelore e Nelore x Bos taurus), as frequências alélicas e genotípicas dos polimorfismos $C A S T / X m n I$, do gene da calpastatina, e CAPN530, do gene da calpaína, bem como avaliar a ocorrência de associações entre esses polimorfismos e características da carcaça e da carne produzida. Trezentos animais - 114 Nelore, 67 Angus x Nelore, 44 Rubia Galega x Nelore, 41 Canchim, 19 tricross Brangus e 15 tricross Braunvieh - foram genotipados por PCR-RFLP e fenotipados para área de olho de lombo (AOL), cobertura de gordura subcutânea (CGS), gordura intramuscular (GI), força de cisalhamento (FC) e índice de fragmentação miofibrilar (IFM). A ocorrência dos dois alelos dos polimorfismos de nucleotídeo único (SNPs) CAST/XmnI e CAPN530 em animais B. indicus, que viabilizou estudos de associação em gado Nelore puro e cruzado, foi demonstrada pela primeira vez neste trabalho. Nenhuma relação foi encontrada entre os SNPs dos genes CAST e CAPN1 e as características de crescimento (AOL) ou deposição de gordura (CGS e GI), já que a calpastatina e a $\mu$-calpaína não estão fisiologicamente envolvidas com essas características. Os resultados de associação entre os genótipos e a maciez da carne maturada (avaliada por FC e IFM) mostraram a pouca utilidade desses marcadores na seleção de bovinos Nelore puros ou cruzados com B. taurus.

Termos para indexação: Bos indicus, gene da calpaína, gene da calpastatina, maciez da carne, polimorfismos de nucleotídeo único.

\section{Introduction}

Tenderness is very relevant to beef consumers and is, therefore, a trait of interest for animal selection. The breakdown of myofibrillar proteins controlled by the $\mu$-calpain enzyme and modulated by its inhibitor, calpastatin, is the main mechanism of post-mortem meat tenderization (Delgado et al., 2001). When calpastatin activity increases, it reduces $\mu$-calpain activity, with 
a negative effect on meat tenderness (Pringle et al., 1997). Therefore, genes encoding calpastatin (CAST) and $\mu$-calpain $(C A P N 1)$ are considered important functional candidates for meat tenderness in livestock.

The CAST gene was mapped to chromosome BTA7 (Bishop et al., 1993), and the CAPN1 gene, to the telomeric end of the BTA29 chromosome, the same position verified for meat tenderness QTL (Smith et al., 2000). Chung et al. (2001a) detected genetic variants at intron 6 of bovine $C A S T$, which can be identified by PCR-RFLP using the XmnI restriction enzyme. They also found some evidence indicating that genotyping this polymorphism could help identify animals with distinct calpastatin enzymatic activity. Two non-synonymous single nucleotide polymorphisms (SNPs) - CAPN316 (located in exon 9) and CAPN530 (located in exon 14) in the gene CAPN1 have been associated with meat traits in Bos taurus beef breeds (Page et al., 2002, 2004; Corva et al., 2007). Rincon \& Medrano (2006) developed a PCR-RFLP method for genotyping the CAPN530 polymorphism using the PsyI enzyme. However, this marker failed to show segregation in $B$. indicus cattle of the Brahman breed (Casas et al., 2005), discouraging association studies between this SNP and meat quality in other zebu-influenced breeds.

According to Casas et al. (2005), polymorphisms that segregate and associate with traits of interest in $B$. taurus may or may not segregate in B. indicus. Thus, it is necessary to develop and use other markers in candidate genes or chromosomal regions, to allow association studies in B. indicus. It is also important to consider major variations in allelic frequencies between breeds, even within subspecies. Furthermore, association results for molecular markers and production traits obtained in B. taurus populations are not directly applicable to $B$. indicus populations, because allelic substitution effects are specific to each population and its environment.

The objective of this work was to estimate the allelic and genotypic frequencies of the CAST/XmnI and CAPN530 polymorphisms in different beef genetic groups (Nelore and Nelore x B. taurus), as well as to determine the occurrence of associations between these polymorphisms and carcass and meat traits.

\section{Materials and Methods}

Samples of Nelore (B. indicus, $\mathrm{n}=114)$, Angus $x$ Nelore $(1 / 2$ B. taurus $+1 / 2$ B. indicus, $\mathrm{n}=67)$,
Canchim $(5 / 8$ B. taurus $+3 / 8$ B. indicus, $\mathrm{n}=41)$, Brangus three-way cross $(9 / 16$ B. taurus $+7 / 16$ B. indicus, $\mathrm{n}=19)$ and Braunvieh three-way cross (3/4 B. taurus + $1 / 4 B$. indicus, $\mathrm{n}=15$ ) were analyzed. These animals, originating from commercial herds of seven farms, were bred in 2003, 2005, 2006 and 2007 in the feedlot of the Faculdade de Medicina Veterinária e Zootecnia of the Universidade Estadual Paulista, Botucatu, SP, Brazil, using an intensive system denominated "superprecoce", previously detailed by Curi et al. (2005). The remaining 44 samples representing the cross between Rubia Gallega sires (B. taurus) and Nelore dams (Rubia Gallega x Nelore: $1 / 2$ B. taurus + $1 / 2 B$. indicus), were raised in a semi-intensive system during 2006. The genetic composition of each group was described by Curi et al. (2009). The 300 animals used in the trial, 32 females and 268 males, were bred according to the Brazilian legislation for animal wellbeing (protocol n $89 / 2006$-CEEA issued by the Comitê de Ética em Experimentação Animal - CEEA, of the Faculdade de Medicina Veterinária e Zootecnia of the Universidade Estadual Paulista, Botucatu, SP, Brazil) and slaughtered at 15, 17 and 19 months of age.

After slaughter in collaborating abattoirs, the carcasses were identified and chilled for 24 hours. Two 2.54-cm thick samples of the longissimus dorsi muscle were then removed from an area between the $11^{\text {th }}$ and $13^{\text {th }}$ ribs of the left half of each carcass.

Samples collected between the $12^{\text {th }}$ and $13^{\text {th }}$ ribs provided rib-eye area (REA), back-fat thickness (BT) and shear force (SF) measurements. Samples collected between the $11^{\text {th }}$ and $12^{\text {th }}$ ribs were used to measure the myofibrillar fragmentation index (MFI) and intramuscular fat (IF, percentage of total lipids), as well as for the extraction of genomic DNA. The REA was measured by the quadrant-point method and the BT was determined with the aid of a ruler, both according to the USDA Quality Grade protocol (United States Department of Agriculture, 1997). After these initial measurements, carried out in the slaughterhouse, the samples of longissimus dorsi were deboned, vacuum wrapped and aged under controlled temperature (between 1 and $2^{\circ} \mathrm{C}$ ) for 14 days, followed by freezing at $-20^{\circ} \mathrm{C}$. The other phenotypic traits, SF, MFI and IF, were determined in the laboratory following methods described by Wheeler et al. (1995), Culler et al. (1978) and Bligh \& Dyer (1959) respectively.

Pesq. agropec. bras., Brasília, v.44, n.12, p.1660-1666, dez. 2009 
Genomic DNA was extracted from meat samples (250 mg) by the non-phenolic method, with digestion with proteinase $\mathrm{K}$ and precipitation with $\mathrm{NaCl}$ and alcohol (Sambroock et al., 1989).

CAST and CAPN1 genotyping was done by the PCR-RFLP method. To determine the $\mathrm{A}$ and $\mathrm{B}$ alleles of the CAST SNP, a fragment of approximately 2,000 base pairs located at intron 6 was amplified with forward 5' - AGC AGC CAC CAT CAG AGA AA - 3' and reverse 5' - TCA GCT GGT TCG GCA GAT - 3' primers and digested by the $X m n I$ restriction enzyme (Chung et al., 2001a). To identify the A and G alleles of CAPN530 polymorphism, a fragment of 341 base pairs located at exon 14 was amplified with forward 5' - CGT TTC TTC TCA GAG AAG AGC GCA GG G A - 3' and reverse 5' - CCT GCG CCA TTA CTA TCG ATC GCA AAG T - 3' primers and digested by the PsyI restriction enzyme (Rincon \& Medrano, 2006). After digestion of the amplification products, the DNA fragments of CAST and CAPN1 genes were separated in agarose gel ( 2 and $3 \%$ respectively).

The individual genotypes were determined by DNA fragment size analysis (measured in base pairs, bp), by comparison with a standard molecular weight of $100 \mathrm{bp}$. The allelic and genotypic frequencies were calculated for each polymorphism according to Weir (1996). The differences in allele frequency within and between the genetic groups studied was calculated using contingency tables (Curi \& Moraes, 1981) adapted from Goodman (1965).

For the association studies, the traits of interest were analyzed using the general linear model (GLM) of the Statistical Analysis System (SAS Institute, 2004) program, and the least square means of the genotypes were compared by the Tukey's test. The Bonferroni correction was applied to analyses involving multiple comparisons.
The linear model for adjustment of quantitative variables included the genotype and the contemporary group effects as follows: $Y_{i j k}=\mu+G_{i}+C_{j}+e_{i j k}$, where $Y_{i j k}$ is the trait of interest, $\mu$ is the general mean, $G_{i}$ is the fixed effect of $i^{\text {th }}$ genotype $(i=1, \ldots, 3), \mathrm{CG}_{\mathrm{j}}$ is the fixed effect of $j^{\text {th }}$ contemporary group $(j=1, \ldots, 13)$, and $e_{i j k}$ is the random error. The definition of contemporary groups included variations of genetic group, sex, age of slaughter, feedlot year and farm of origin. These variations could not be considered separately in the model, since there is an important confounding among them. The bull effect was not included in the model, since the number of genotyped offspring of individual bulls was very small. Thus, due to the large number of parents, the possibility of confounding between the genotype and bull effects on the evaluated traits was diluted. The interactions between SNPs and the studied genetic groups were not significant, and were not included in the final analysis.

\section{Results and Discussion}

The CAST/XmnI polymorphism segregated in the six genetic groups studied with a significantly higher frequency of the A allele in all analyses (Table 1). The A allele frequency was significantly higher in the Angus x Nelore and Rubia Gallega x Nelore groups than in the Nelore and Canchim groups. Brangus and Braunvieh three-way crosses had an intermediate A allele frequency in comparison to the groups that differed statistically. Homozygous AA followed by heterozygous $\mathrm{AB}$ were the most frequent genotypes in all but the Canchim group, in which the homozygous $\mathrm{BB}$ was the second most frequent genotype.

No previous studies with $B$. indicus were found to adequately compare the results for allelic frequencies

Table 1. Allelic and genotypic frequencies for the $C A S T / X m n I$ polymorphism in the different genetic groups and in the total animal sample ${ }^{(1)}$.

\begin{tabular}{|c|c|c|c|c|c|}
\hline \multirow[t]{2}{*}{ Genetic group $^{(2)}$} & \multicolumn{2}{|c|}{ Allelic frequency } & \multicolumn{3}{|c|}{ Genotypic frequency } \\
\hline & A & $\mathrm{B}$ & $\mathrm{AA}$ & $\mathrm{AB}$ & $\mathrm{BB}$ \\
\hline Nelore (114) & $0.636 \mathrm{Ba}$ & $0.364 \mathrm{Ab}$ & 0.438 & 0.395 & 0.167 \\
\hline Angus x Nelore (67) & $0.873 \mathrm{Aa}$ & $0.127 \mathrm{Bb}$ & 0.746 & 0.254 & 0.000 \\
\hline Rubia Gallega x Nelore (44) & $0.795 \mathrm{Aa}$ & $0.205 \mathrm{Bb}$ & 0.659 & 0.273 & 0.068 \\
\hline Canchim (41) & $0.621 \mathrm{Ba}$ & $0.379 \mathrm{Ab}$ & 0.512 & 0.219 & 0.269 \\
\hline Brangus three-way cross (19) & $0.790 \mathrm{ABa}$ & $0.210 \mathrm{ABb}$ & 0.632 & 0.316 & 0.052 \\
\hline Braunvieh three-way cross (15) & $0.800 \mathrm{ABa}$ & $0.200 \mathrm{ABb}$ & 0.600 & 0.400 & 0.000 \\
\hline Total $(300)$ & 0.732 & 0.268 & 0.577 & 0.310 & 0.113 \\
\hline
\end{tabular}

${ }^{(1)}$ Means followed by equal letters, uppercase among genetic groups and lowercase within genetic groups, do not differ by the Goodman test, at $5 \%$ probability. ${ }^{(2)}$ The number between parentheses indicates the number of animals in each genetic group. 
of CAST/XmnI. Nevertheless, the present findings and the frequencies of 0.75 and 0.25 for alleles $\mathrm{A}$ and $\mathrm{B}$, described in B. taurus animals of the Angus breed by Chung et al. (2001a), suggest that the A allele frequency is higher than the B allele frequency in B. taurus and in $B$. indicus. Consequently, the absence of differences in $C A S T / X m n I$ allele frequencies between $B$. indicus and $B$. taurus suggests a lack of association between this polymorphism and meat tenderness, a trait that differs between the subspecies (Wheeler et al., 1994).

Results for association analyses between CAST/ $X m n I$ genotypes and studied traits (Table 2) were not significant ( $\mathrm{p}>0.05)$. In spite of the CAST/XmnI being a SNP in a non-coding region, it could be linked or in linkage disequilibrium with causative polymorphisms associated to phenotype differences. Also, no codifying RNA transcript from intronic regions are involved in a number of biological processes, such as controlling transcriptional and post-transcriptional levels of gene expression (Nakaya et al., 2007). Thus, intronic polymorphisms have gained importance as possible causative SNP and are not to be overlooked. However, as in Chung et al. (2001b), the results of the present trial show no association between the CAST/XmnI polymorphism and meat tenderness based on shear force or myofibrillar fragmentation index. Even with a small number of animals genotyped, 47 B. taurus animals of the Angus breed, Chung et al. (2001b) found that genotypes had significant effect on calpastatin activity, although they could not explain the observed variation in meat tenderness. Chung et al. (2001b) and the present work showed greater meat tenderness in animals with two copies of the A allele, that were, however, not statistically significant. AA animals had lower shear force and higher myofibrillar fragmentation index when comparing minimum square means. These results may be explained by the low CAST/ $X m n I$ effect or by the weak disequilibrium linkage between this polymorphism and the causative mutation. Considering the size of the effect, the association between $C A S T / X m n I$ and the evaluated traits may have been significant with more animals in the sample. The weak linkage disequilibrium hypothesis showed that other polymorphisms described in the CAST gene were closely related to variation in meat tenderness, namely the SNP A2959G (access number AF159246), at region 3' UTR, and G/C (nucleotide 282 of access number AY008267), at intron 5, identified by Barendse (2004) and Schenkel et al. (2006) respectively. Curi et al. (2008) reported the genotyping of A2959G (AF159246) SNP of bovine CAST gene by PCR-RFLP technique for the first time. The accuracy of the method was confirmed through the direct sequencing of PCR products of nine individuals. The lack of connection between allelic forms of the CAST gene and growth related traits (such as REA) and fat (BT and IF) was expected since, in theory, calpastatin is not involved in their physiology. However, it may be possible to find linkage disequilibrium between this marker and functional polymorphisms in surrounding genes, as well as the possibility of pleiotropic effects. Chung et al. (2001b) found significant associations between CAST polymorphisms and percentage of kidney, pelvic and heart fat, and Schenkel et al. (2006) associated the gene with carcass fat yield.

The CAPN530 polymorphism segregated in all genetic groups studied (Table 3). The A allele frequency was lower than the $G$ allele frequency in all analyses. There were no significant differences in allelic frequencies between genetic groups. The AA genotype was less frequent in all groups. Higher GG frequency was prevalent in all but one group, the Rubia Gallega $x$ Nelore, in which the AG genotype was most prominent. In contrast with the results presented by Casas et al. (2005), which showed absence of the A allele in a $B$. indicus population of the Brahman breed, this study revealed a $21.9 \%$ frequency in Nelore B. indicus. Thus, for the first time, it was possible to study the association between this polymorphism and traits of economical interest in $B$. indicus bovines. The

Table 2. Least square means and standard errors of the rib-eye area (REA), back-fat thickness (BT), intramuscular fat (IF), shear force (SF) and myofibrillar fragmentation index (MFI) determined for genotypes of the CAST/XmnI polymorphism.

\begin{tabular}{llllll}
\hline Genotype $(1)$ & REA $\left(\mathrm{cm}^{2}\right)$ & BT $(\mathrm{mm})$ & \multicolumn{1}{c}{ IF $(\%)$} & \multicolumn{1}{c}{ SF $\left(\mathrm{kgf} \mathrm{cm}^{-2}\right)$} & \multicolumn{1}{c}{ MFI } \\
\hline AA (163) & $72.36 \pm 0.75$ & $4.00 \pm 0.12$ & $1.47 \pm 0.07$ & $3.54 \pm 0.06$ & $75.52 \pm 1.48$ \\
AB (91) & $70.52 \pm 0.92$ & $3.89 \pm 0.45$ & $1.47 \pm 0.09 \mathrm{~A}$ & $3.75 \pm 0.08 \mathrm{~A}$ & $64.94 \pm 1.81$ \\
BB (30) & $71.22 \pm 1.56$ & $4.11 \pm 0.25$ & $1.35 \pm 0.15$ & $3.91 \pm 0.13$ & $70.93 \pm 3.04$ \\
\hline
\end{tabular}

${ }^{(1)}$ The numbers between parentheses indicate the number of animals from each genotype. 
results presented here and elsewhere (Page et al., 2004; White et al., 2005; Corva et al., 2007) suggest that the A allele frequency of CAPN530 is lower then the G frequency in both $B$. taurus and B. indicus animals, and that the A allele occurrence is not extremely different between breeds. In two different $B$. taurus populations - a commercial herd, Simmental x Angus, and a research herd, GPE Cycle 7 -, Page et al. (2004) showed frequencies of 37 and $28 \%$ for the A allele. White et al. (2005) found a $14 \%$ frequency in a study with animals that combined $B$. taurus and $B$. indicus influence. Finally, Corva et al. (2007) described frequencies between 2 and $18 \%$ in four genetic groups formed by the crosses of Angus, Hereford and Limousin breeds (all B. taurus). Thus, like for CAST/ $X m n \mathrm{I}$, it appears there is not great difference between $B$. taurus e $B$. indicus for the allele frequencies of the CAPN530, and this may indicate a lack of association between polymorphism and meat tenderness.

The analyses also showed no association ( $p>0.05)$ between genotypes of CAPN530 and phenotypes (Table 4). The CAPN530 polymorphism in the CAPN1 gene is a guanine ( $\mathrm{G}$ allele) to adenine (A allele) substitution that causes a valine to isoleucine change at codon 530, domain III of the $\mu$-calpain enzyme. The alteration between two apolar aminoacids is relatively conservative, although it may change protein stability and assemblage, thus affecting proteolytic activity (Page et al., 2002). Page et al. (2002, 2004) and Corva et al. (2007) found evidence of the association between polymorphism and meat tenderness. Interestingly, while Page et al. $(2002,2004)$ report a favorable effect of the G allele, Corva et al. (2007) dispute the superior meat tenderness - smaller shear force values - of the AG genotype in comparison with the GG genotype. Analogous to conclusions reported by White et al. (2005), the present work failed to show association between genotypes of CAPN530 and meat tenderness. In addition to the environment-genotype interaction, which may produce divergent results even with direct markers within a breed, this disagreement can be due to differences: in disequilibrium or in the linkage phase between markers and quantitative trait locus (QTL); in epistatic interactions affecting the candidate gene; and in the magnitude of the effect of the candidate gene over the phenotype (Curi et al., 2005). These differences often underpin comparisons amongst populations and breeds, and in bovines they normally concur to the diversity of two subspecies. Hence, the contrast between the findings of Page et al. (2002, 2004), the present results and those of White et al. (2005) may be understood, as the first works mentioned only used

Table 3. Allelic and genotypic frequencies for the CAPN530 polymorphism in the different genetic groups and in the total animal sample ${ }^{(1)}$.

\begin{tabular}{|c|c|c|c|c|c|}
\hline \multirow[t]{2}{*}{ Genetic group $^{(2)}$} & \multicolumn{2}{|c|}{ Allelic frequency } & \multicolumn{3}{|c|}{ Genotypic frequency } \\
\hline & A & G & AA & $\mathrm{AG}$ & GG \\
\hline Nelore (114) & $0.219 \mathrm{Ab}$ & $0.781 \mathrm{Aa}$ & 0.070 & 0.298 & 0.632 \\
\hline Angus x Nelore (67) & $0.343 \mathrm{Ab}$ & $0.657 \mathrm{Aa}$ & 0.134 & 0.418 & 0.448 \\
\hline Rubia Gallega x Nelore (44) & $0.329 \mathrm{Ab}$ & $0.671 \mathrm{Aa}$ & 0.091 & 0.477 & 0.432 \\
\hline Canchim (41) & $0.219 \mathrm{Ab}$ & $0.781 \mathrm{Aa}$ & 0.121 & 0.195 & 0.684 \\
\hline Brangus three-way cross (19) & $0.263 \mathrm{Ab}$ & $0.737 \mathrm{Aa}$ & 0.105 & 0.316 & 0.579 \\
\hline Braunvieh three-way cross (15) & $0.367 \mathrm{Aa}$ & $0.633 \mathrm{Aa}$ & 0.200 & 0.333 & 0.467 \\
\hline Total $(300)$ & 0.273 & 0.727 & 0.103 & 0.340 & 0.557 \\
\hline
\end{tabular}

${ }^{(1)}$ Means followed by equal letters, uppercase among genetic groups and lowercase within genetic groups, do not differ by the Goodman test, at $5 \%$ probability. ${ }^{(2)}$ The number between parentheses indicates the number of animals in each genetic group.

Table 4. Least square means and standard errors of the rib-eye area (REA), back-fat thickness (BT), intramuscular fat (IF), shear force (SF) and myofibrillar fragmentation index (MFI) determined for genotypes of the CAPN530 polymorphism.

\begin{tabular}{|c|c|c|c|c|c|}
\hline Genotype $^{(1)}$ & $\operatorname{REA}\left(\mathrm{cm}^{2}\right)$ & BT (mm) & IF (\%) & $\mathrm{SF}\left(\mathrm{kgf} \mathrm{\textrm {cm } ^ { - 2 } )}\right.$ & MFI \\
\hline $\mathrm{AA}(30)$ & $73.43 \pm 1.59$ & $3.74 \pm 0.26 \mathrm{~A}$ & $1.31 \pm 0.16$ & $3.74 \pm 0.14$ & $69.17 \pm 3.14$ \\
\hline AG (99) & $70.42 \pm 0.93$ & $4.12 \pm 0.15$ & $1.58 \pm 0.09$ & $3.65 \pm 0.08$ & $71.84 \pm 1.82$ \\
\hline GG (158) & $71.91 \pm 0.72$ & $3.94 \pm 0.12$ & $1.42 \pm 0.07$ & $3.65 \pm 0.06$ & $74.07 \pm 1.41$ \\
\hline
\end{tabular}

${ }^{(1)}$ The number between parentheses indicates the number of animals from each genotype. 
B. taurus animals, while the last two also included $B$. indicus animals. Overall, these results indicate that the CAPN530 SNP is not a functional marker for variation in beef tenderness. Also, in B. indicus populations it is not linked or in strong linkage disequilibrium with the causative polymorphism, which confirms that polymorphism is useless in marker-assisted selection for beef herds with a broad genetic background. However, a relatively novel CAPN1 polymorphism, the CAPN4751 SNP, has shown great potential as a marker for meat tenderness selection in $B$. taurus, $B$. indicus and B. indicus $\mathrm{x}$ B. taurus beef herds (White et al., 2005; Van Eenennaam et al., 2007). As expected, no relation between allelic forms of the CAPN1 gene and the growth and fat traits (REA, BT and IF) was found. On the other hand, with the possibility of linkage disequilibrium between the CAPN1 and surrounding genes or of pleiotropic effects, positive associations between variants of the gene and carcass traits were described (Juszczuk-Kubiak et al., 2004; Casas et al., 2005; Cheong et al., 2008).

\section{Conclusions}

1. Despite novel demonstration of the occurrence of the two alleles of CAST/XmnI and CAPN30 polymorphisms in Bos indicus animals, there is no association between genotypes of these markers and meat tenderness.

2. The analyzed polymorphisms are useless in marker-assisted selection programs for Nelore and their crosses with Bos taurus.

\section{Acknowledgements}

To Fundação de Amparo à Pesquisa do Estado de São Paulo and to Conselho Nacional de Desenvolvimento Cientifico e Tecnológico, for financial support.

\section{References}

BARENDSE, W.J. DNA markers for meat tenderness. US 20040115678A1, 8 Feb. 2002, 17 Jun. 2004.

BISHOP, M.D.; KOOHMARAIE, M.; KILLEFER, J.; KAPPES, S. Rapid communication: restriction fragment length polymorphisms in the bovine calpastatin gene. Journal of Animal Science, v.71, p.2277, 1993.

BLIGH, E.G.; DYER, W.J. A rapid method of total lipid extraction and purification. Canadian Journal of Biochemistry and Physiology, v.37, p.911-917, 1959.
CASAS, E.; WHITE, S.N.; RILEY, D.G.; SMITH, T.P.L.; BRENNEMAN, R.A.; OLSON, T.A.; JOHNSON, D.D.; COLEMAN, S.W.; BENNETT, G.L.; CHASE JUNIOR, C.C. Assessment of single nucleotide polymorphisms in genes residing on chromosomes 14 and 29 for association with carcass composition traits in Bos indicus cattle. Journal of Animal Science, v.83, p.1319, 2005.

CHEONG, H.S.; YOON, D.H.; PARK, B.L.; KIM, L.H.; BAE, J.S.; NAMGOONG, S.; LEE, H.W.; HAN, C.S.; KIM, J.O.; CHEONG, I.C.; SHIN, H.D. A single nucleotide polymorphism in CAPN1 associated with marbling score in Korean cattle. BMC Genetics, v.9, 2008. Doi:10.1186/1471-2156-9-33.

CHUNG, H.Y.; DAVIS, M.E.; HINES, H.C. Genetic variants detected by PCR-RFLP in intron 6 of the bovine calpastatin gene. Animal Genetics, v.32, p.53, 2001a.

CHUNG, H.Y.; DAVIS, M.E.; HINES, H.C. Relationship of two PCR-RFLP in the bovine calpastatin gene with calpastatin activity, meat tenderness and carcass traits. Ohio Agricultural Research Development Center, v.181, p.7-34, $2001 \mathrm{~b}$.

CORVA, P.; SORIA, L.; SCHOR, A.; VILLARREAL, E.; CENCI, M.P.; MOTTER, M.; MEZZADRA, C.; MELUCCI, L.; MIQUEL, C.; PAVÁN, E.; DEPETRIS, G.; SANTINI, F.; NAÓN, J.G. Association of CAPN1 and CAST gene polymorphisms with meat tenderness in Bos taurus beef cattle from Argentina. Genetics and Molecular Biology, v.30, p.1064-1069, 2007.

CULLER, R.D.; PARRISH JUNIOR, F.C.; SMITH, G.C.; CROSS, H.R. Relationship of myofibril fragmentation index to certain chemical, physical and sensory characteristics of bovine longissimus muscle. Journal of Food Science, v.43, p.1177-1180, 1978.

CURI, P.R.; MORAES, R.V. Associação, homogeneidade e contrastes entre proporções em tabelas contendo distribuições multinomiais. Ciência e Cultura, v.33, p.712-722, 1981.

CURI, R.A.; CHARDULO, L.A.L.; MASON, M.C.; ARRIGONI, M.D.B.; SILVEIRA, A.C.; OLIVEIRA, H.N. de. Effect of single nucleotide polymorphisms of CAPN1 and CAST genes on meat traits in Nellore beef cattle (Bos indicus) and in their crosses with Bos taurus. Animal Genetics, v.40, p.456-462, 2009.

CURI, R.A.; CHARDULO, L.A.L.; SILVEIRA, A.C.; OLIVEIRA, H.N. de. Alternative genotyping method for the single nucleotide polymorphism A2959G (AF159246) of the bovine CAST gene. Pesquisa Agropecuária Brasileira, v.43, p.657-659, 2008.

CURI, R.A.; OLIVEIRA, H.N. de; GIMENES, M.A.; SILVEIRA, A.C.; LOPES, C.R. Effects of CSN3 and $L G B$ gene polymorphisms on production traits in beef cattle. Genetics and Molecular Biology, v.28, p.262-266, 2005.

DELGADO, E.F.; GEESINK, G.H.; MARCHELLO, J.A.; GOLL, D.E.; KOOHMARAIE, M. Properties of myofibril-bound calpain activity in longissimus muscle of callipyge and normal sheep. Journal of Animal Science, v.79, p.2097-2107, 2001.

GOODMAN, L.A. On simultaneous confidence intervals for multinomial proportions. Technometrics, v.7, p.247-254, 1965.

JUSZCZUK-KUBIAK, E.; SAKOWSKI, T.; FLISIKOWSKI, K.; WICIÑSKA, K.; OPRZADEK, J.; ROSOCHACKI, S.J. Bovine $\mu$-calpain (CAPN1) gene: new SNP within intron 14. Journal of Applied Genetics, v.45, p.457-460, 2004.

Pesq. agropec. bras., Brasília, v.44, n.12, p.1660-1666, dez. 2009 
NAKAYA, H.L.; AMARAL, P.P.; LOURO, R.; LOPES, A.; FACHEL, A.A.; MOREIRA, Y.B.; EL-JUNDI, T.A.; SILVA, A.M. da; REIS, E.M.; VERJOVSKI-ALMEIDA, S. Genome mapping and expression analyses of human intronic noncoding RNAs reveal tissue-specific patterns and enrichment in genes related to regulation of transcription. Genome Biology, v.8, 2007. Doi:10.1186/gb2007-8-3-r43.

PAGE, B.T.; CASAS, E.; HEATON, M.P.; CULLEN, N.G.; HYNDMAN, D.L.; MORRIS, C.A.; CRAWFORD, A.M.; WHEELER, T.L.; KOOHMARAIE, M.; KEELE, J.W.; SMITH, T.P.L. Evaluation of single-nucleotide polymorphisms in CAPN1 for association with meat tenderness in cattle. Journal of Animal Science, v.80, p.3077-3085, 2002.

PAGE, B.T.; CASAS, E.; QUAAS, R.L.; THALLMAN, R.M.; WHEELER, T.L.; SHACKELFORD, S.D.; KOOHMARAIE, M.; WHITE, S.N.; BENNETT, G.L.; KEELE, J.W.; DIKEMAN, M.E.; SMITH, T.P.L. Association of markers in the bovine CAPN1 gene with meat tenderness in large crossbred populations that sample influential industry sires. Journal of Animal Science, v.82, p.3474-3481, 2004.

PRINGLE, T.D.; WILLIAMS, S.E.; LAMB, B.S.; JOHNSON, D.D.; WEST, R.L. Carcass characteristics, the calpain proteinase system, and aged tenderness of Angus and Brahman crossbred steers. Journal of Animal Science, v.75, p.2955-2961, 1997.

RINCON, G.; MEDRANO, J.F. Assays for genotyping single nucleotide polymorphisms in the bovine CAPN1 gene. Animal Genetics, v.37, p.294-295, 2006.

SAMBROOK, J.; FRITSCH, E.F.; MANIATIS, T. Molecular cloning: a laboratory manual. $2^{\text {nd }}$ ed. New York: Cold Spring Harbor Laboratory Press, 1989. Paginação irregular.

SAS INSTITUTE. SAS/STAT: user's guide. Version 9.1. Cary: SAS Institute, 2004.
SCHENKEL, F.S.; MILLER, S.P.; JIANG, Z.; MANDELL, I.B.; YE, X.; LI, H.; WILTON, J.W. Association of a single nucleotide polymorphism in the calpastatin gene with carcass and meat quality traits of beef cattle. Journal of Animal Science, v.84, p.291-299, 2006.

SMITH, T.P.L.; CASAS, E.; REXROAD, C.E.; KAPPES, S.M.; KEELE, J.W. Bovine CAPN1 maps to a region of BTA29 containing a quantitative trait locus for meat tenderness. Journal of Animal Science, v.78, p.2589-2594, 2000.

UNITED STATES DEPARTMENT OF AGRICULTURE. United States standards for grades of carcass beef. Washington: USDA, 1997. $17 \mathrm{p}$.

VAN EENENNAAM, A.L.; LI, J.; THALLMAN, R.M.; QUAAS, R.L.; DIKEMAN, M.E.; GILL, C.A.; FRANKE, D.E.; THOMAS, M.G. Validation of commercial DNA tests for quantitative beef quality traits. Journal of Animal Science, v.85, p.891-900, 2007.

WEIR, B.S. Genetic data analysis II: methods for discrete population genetic data. $2^{\text {nd }}$ ed. Sunderland: Sinauer Associates, 1996. 445p.

WHEELER, T.L.; CUNDIFF, L.V.; KOCH, R.M. Effect of marbling degree on beef palatability in Bos taurus and Bos indicus cattle. Journal of Animal Science, v.72, p.3145-3151, 1994.

WHEELER, T.L.; KOOHMARAIE, M.; SHACKELFORD, S.D. Standardized Warner-Bratzler shear force procedures for meat tenderness measurement. Clay Center: USDA, 1995. 7p.

WHITE, S.N.; CASAS, E.; WHEELER, T.L.; SHACKELFORD, S.D.; KOOHMARAIE, M.; RILEY, D.G.; CHASE JUNIOR, C.C.; JOHNSON, D.D.; KEELE, J.W.; SMITH, T.P.L. A new single nucleotide polymorphism in $C A P N 1$ extends the current tenderness marker test to include cattle of Bos indicus, Bos taurus, and crossbred descent. Journal of Animal Science, v.83, p.2001-2008, 2005.

$\overline{\text { Received on August 24, } 2009 \text { and accepted on November 22, } 2009}$ 